\title{
Mediastinal Germ Cell Tumor Regional Lymph Nodes TNM Finding
}

National Cancer Institute

\section{Source}

National Cancer Institute. Mediastinal Germ Cell Tumor Regional Lymph Nodes TNM

Finding. NCl Thesaurus. Code C146841.

A TNM finding about one or more characteristics of a mediastinal germ cell tumor as they pertain to staging of regional lymph nodes. (WHO Classification of Tumors of the Lung, Pleura, Thymus and Heart, 2015) 